\title{
PERCEPTION OF FINANCING MARGINS ON FINANCING DECISIONS AND ITS IMPACT ON CUSTOMER SATISFACTION
}

\author{
Vironica Nurani ${ }^{1}$ \\ ${ }^{1}$ Faculty of Economics, Universitas negeri Jakarta \\ Jakarta, Indonesia \\ vironicanurani@gmail.com \\ Mohamad Rizan \\ ${ }^{2}$ Faculty of Economics, Universitas negeri Jakarta \\ Jakarta, Indonesia \\ mohamadrizan72@gmail.com \\ Saparuddin Mukhtar ${ }^{3}$ \\ ${ }^{3}$ Faculty of Economics, Universitas negeri Jakarta \\ Jakarta, Indonesia \\ saparuddin@unj.ac.id
}

\begin{abstract}
The rise of digitalization of financial services has led to the emergence of many fintech (financial techology) start-ups. However, because fintech startups have several risks, the Bank remains the main option in selecting financing / credit service products for bankable people. This research was conducted at PT Bank Syariah Mandiri with a purposive sampling method. The data was collected by distributing questionnaires using a Likert scale. The analysis technique used is Structural Equation Modeling (SEM) to calculate the effect of each variable. The results of the study reveal that service quality has a positive and significant effect on the decision to request financing, the perception of the margin of financing has a positive and significant effect on the decision on financing application, the quality of service has no positive and insignificant effect on customer satisfaction, the perception of the size of the financing margin has a positive and significant effect on satisfaction. Customer, the decision to request financing has a positive and significant effect on customer satisfaction, service quality has a positive and significant effect on customer satisfaction, which is mediated by the decision on a financing request, the perception of the size of the financing margin
\end{abstract}


has a positive and significant effect on the variable of customer satisfaction, which is mediated by the variable of financing request decision. Based on the result, banking services can increase financing margins that this is can relate with customer purchasing decision.

Keywords: Service Quality, Perceptions, Decisions, Satisfaction

\section{INTRODUCTION}

The rise of digitalization of financial services has led to the emergence of many fintech (financial technology) start-ups. However, because fintech start-ups have several risks, the Bank remains the primary option in selecting financing/credit service products for bankable people.

In line with a customer survey conducted by BI, it is estimated that financing/credit growth in 2018 will reach $11.06 \%$ YoY, higher than the realization of financing growth in 2017 of 8.2\% YoY. (www.bi.go.id, 2018).

The Indonesian population, predominantly Muslim, is a potential market for sharia products and services, but this potential has not been optimally exploited. This can be seen from Islamic banking's market share to national banks, which amounted to $5.73 \%$ in July 2018 (Infobank Magazine, 2018).

Survey one has conducted an online survey of people who have used consumer financing services, which is a mortgage product. There are several factors that consumers consider in choosing a KPR. The factors that are taken into consideration are the credit interest/financing margin $(83.7 \%)$, the financing period $(58.1 \%)$, the financing ceiling given $(55.8 \%)$, while the processing time and insurance are in fourth and fifth place (Property-in Magazine, 2018).

In the 2018 Top Brand Award conducted by Frontier Consulting Group, BSM KPR products are among the top brands in the home financing product category. This leading brand has won 3 parameters: top of mind share, top of market share, and top of commitment share. In this study, a questionnaire was developed specifically for the Top Brand Index (TBI) survey.

For the bank \& finance category involving conventional and sharia, the KPR Bank Syariah Mandiri (KPR BSM) product won the top brand award in the KPR category with 
a TBI of 4.1\%. In fourth place after KPR BTN (TBI 53.6\%), KPR BRI (TBI 11.2\%), KPR BCA (5.9\%), and BNI Griya (5.5\%) (topbrand-award.com, 2018).

Banks need quality services in attracting public interest in conducting financial transactions. Service quality is the level of excellence expected, and control over this excellence is carried out to fulfill customer desires (Tjiptono, 2007).

When viewed from the customer's point of view, price is often used as an indicator of value when it is related to the perceived benefits of using a service. The higher the customer's worth, the higher the customer satisfaction (Tjiptono, 2007).

The determination of the interest rate for a conventional bank determines the price of commodities that are traded by the bank. In Islamic banking, it is known as the financing margin. The determination of interest rates is generally classified into two, namely: riskbased and market interest rates (IBI, 2016).

Based on Deery (2016) and Vinansius (2015) research, price and service quality affect customer satisfaction. This is also supported by research by Suzzy (2017) that prices have a positive and significant effect on customer satisfaction. Meanwhile, according to Laksana (2011), the size of the financing margin and service quality have a positive and significant effect on customer decisions in making financing.

Bank employees are well educated compared to the general public regarding bank services themselves because employees work with banking services on a daily basis. So, it is hoped that bank employees are included in the well literate category, which is to have knowledge and confidence about financial service institutions and financial service products, including features, benefits and risks, rights and obligations related to financial products and services, as well as having skills in using financial products and services (www.bi.go.id, 2018).

Bank employees were chosen because to facilitate sampling. In addition, this research is expected to be developed by the bank's internal party in conducting a study of employee internal financing/soft loans as a form of employee retention and appreciation.

According to customer needs, the importance of service quality factors and the perception of large financing margins increase the market share of sharia financing, which is still at $5.7 \%$. Hence, researchers feel the need to conduct a study. 


\section{LITERATURE REVIEW}

According to Lovelock \& Wirtz (2011), service quality is the result of an evaluation process where customers compare their perceptions of service delivery and the results they have expected.

According to Ratmiko (2005), service quality is an invisible activity that occurs due to interactions between consumers and employees or other things provided by the service provider company to solve customer or consumer problems.

Price is an amount of money charged on a particular product to get some products/services, and consumers must spend money according to the agreed price. (Sunyoto, 2012). In Islamic banks, there is the term financing margin. The amount of the financing margin is stated in the nominal rupiah form and the pre-determined ratio (profit-sharing portion) according to the financing contract used. The price in Islamic banking is the cost of goods plus the agreed margin.

According to Kottler \& Armstrong (2001), a purchase decision is a stage of the buyer's decision-making process where consumers really buy. In this study, the customer decided to apply for financing.

According to Kottler (2007), customer satisfaction stated that customer satisfaction is the level of a person's feelings after comparing the performance (or results) he feels compared to his expectations. Tjiptono (2007) stated that customer satisfaction is the buyer's cognitive situation concerning the equivalence or mismatch between the results obtained compared to the sacrifices made.

\section{Quality of service and decision on financing requests.}

Research by Laksana (2011), Susanti (2016) showed that service quality has a significant positive effect on customer financing request decisions.

H1: service quality has a positive effect on financing request decisions

Primary perceptions of financing margins and decisions on customer financing requests.

Oktavianingrum's research (2016) stated that financing margins positively affect financing customer application decisions.

$\mathrm{H} 2$ : The financing margin has a positive effect on the decision to request financing.

Service quality and customer satisfaction. 
Research by Ika (2015), Widyasari (2017), Susanti (2016) stated that service quality has a positive effect on customer satisfaction.

H3: Service quality has a positive effect on customer satisfaction.

Primary perceptions of financing margins and customer satisfaction.

Research by Susanti (2016) and Laksana (2011) stated that financing margins have a positive effect on customer satisfaction.

H4: perceived financing margin has a positive effect on customer satisfaction.

\section{The decision on financing requests and customer satisfaction.}

Research by Roisah (2013), Ika (2015) stated that the decision to request financing has a positive effect on customer satisfaction.

H5: the decision to request financing has a positive effect on customer satisfaction.

Service quality and financing request decisions and customer satisfaction.

Susanti's research (2016), Ika (2015) stated that service quality has a positive effect on financing customer purchasing decisions that impact customer satisfaction.

H6: service quality has a positive effect on financing request decisions that impact customer satisfaction.

Major perceptions of financing margins, decisions on financing requests, and customer satisfaction.

Research by Ika (2015), Susanti (2016) stated that financing margins have a positive effect on financing customer purchasing decisions, impacting customer satisfaction.

$\mathrm{H} 7$ : financing margins have a positive effect on financing customer purchasing decisions that impact customer satisfaction.

\section{Theoritical Framework}

The hypothesis that has been formulated above can be illustrated in Figure 1 by presenting the research variables, which are latent variables. The indicators used to measure these variables are not shown in the figure.

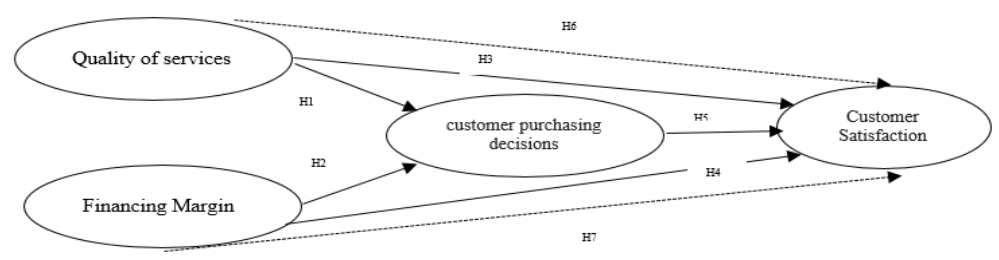

Figure 1. Research Model 


\section{RESEARCH METHOD}

This research was conducted at PT Bank Syariah Mandiri, with a population of mortgage financing customers and a sample of 224 internal customers (employees of PT BSM) with a purposive sampling method. The data was collected by distributing questionnaires using a Likert scale of 1-5 to measure 33 indicators.

The analysis technique used is Structural Equation Modeling (SEM) with AMOS 22.0 program to calculate each variable's effect. The research instrument was tested using the validity and reliability test, while the SEM assumption test was carried out using the normality test and the outlier test. This study uses the CFA (Confirmatory Factor Analysis) analysis technique in SEM, which is used to confirm the most dominant factors in a group of variables. Amos allow to match models for two or more groups simultaneously and summarize how well all of them fit into the chi square statistical value.

\section{RESULT AND DISCUSSION}

\section{Validity Test Results}

The research instrument is said to be valid if it meets the criteria for the value of Critical Ratio (CR) $>1.96$ with Probability $(\mathrm{P})<0.05$. Data processing results show that all indicators have $C R$ values $>1.96$ and $P<0.05$, with the highest $C R$ value of 15.609 on the Kp 5 indicator and the lowest CR value of 8.567 on the Ha 6 indicator and significance $<0.001$. So all indicators in this study are declared valid.

\section{Reliability Test Results}

The research instrument is declared reliable if it has a reliability coefficient or Cronbach's alpha of 0.6 or more. The results of instrument reliability testing for each variable in this study indicate that the Cronbach's alpha value for all variables is above the value of 0.60 , namely the significant perception that the financing margin has a Cronbach's alpha value of 0.888 , service quality has a Cronbach's alpha value of 0.956 , customer satisfaction has a Cronbach's alpha value of 0.946 and the decision to request financing has a Cronbach's alpha value of 0.922 . These results show that all instruments used in this study are reliable.

\section{Normality Test Results}

To perform the normality test on AMOS, it can be seen by comparing the CR (critical ratio) value on the assessment of normality with the expected value to be around \pm 2.58 , both univariate and multivariate. If the $\mathrm{CR}$ value is outside the range of these numbers, 
the data distribution is not normal. The results of normality testing for univariate and multivariate data resulted that the CR (critical ratio) value was outside the \pm 2.58 range, so not all data were normally distributed.

\section{Outlier Test Results.}

Outlier test is done by detecting extreme data by looking at the Mahalanobis value count $<$ Chi Square Distribution Table. This study's outlier test shows that the minimum Mahalanobis distance is 33.051, and the maximum is 146.422. The Chi-Square value obtained from the Chi-Square Distribution Table with 33 degrees of freedom (number of indicators for all variables) at a probability level of 0.05 indicates a value of 541.551. Because the Mahalanobis value is calculated $(146,422)<$ Chi Square Distribution Table $(541,551)$; thus there is no outlier data.

\section{SEM Model Accuracy Test}

In the Confirmatory Factor Analysis, the accuracy of the SEM model was tested. The model is improved by eliminating the error term that most often appears in the M.I. The highest coverage is the AMOS (Modification Indices) output to reduce the chi-square value. The results of the analysis of model adjustments carried out can be seen in the image below: 


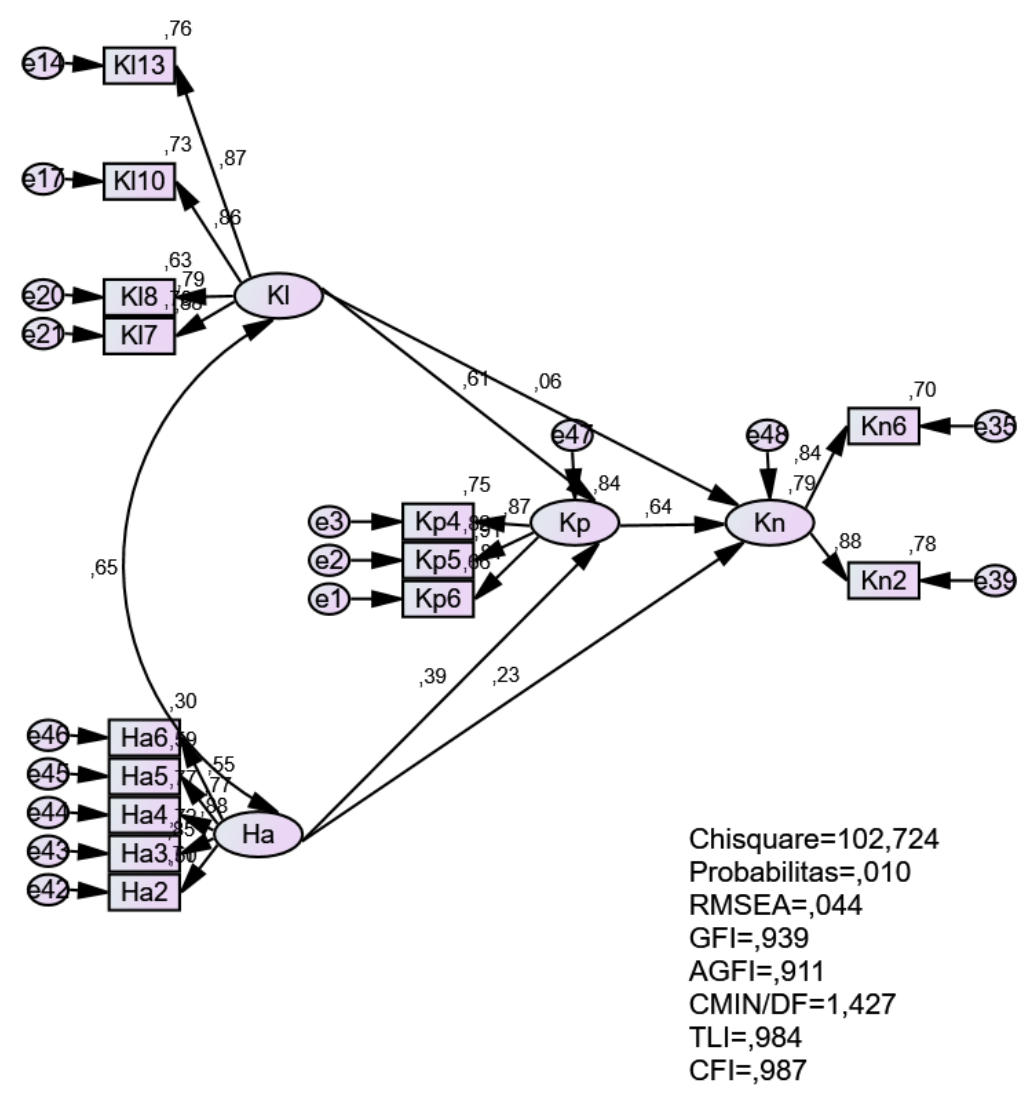

Figure 2. SEM Research Structure After Modification

The results of measuring the final model Goodness of fit criteria are presented in the following table:

Table 1. Fit Measures of SEM Research Model

\begin{tabular}{|c|c|c|c|}
\hline $\begin{array}{c}\text { Goodness of fit- } \\
\text { index }\end{array}$ & $\begin{array}{c}\text { Cut- off } \\
\text { value } \\
\leq 541,551 \\
\text { (fit df) }\end{array}$ & Hasil & Keterangan \\
\hline Chi-Square & $\geq 0,05$ & 0,010 & Fit \\
\hline Probability & $\leq 0,08$ & 0,044 & Fit \\
\hline RMSEA & $\geq 0,90$ & 0,939 & Fit \\
\hline GFI & $\geq 0,90$ & 0,911 & Fit \\
\hline AGFI & $\leq 2,00$ & 1,427 & Fit \\
\hline CMIN/DF & $\geq 0,95$ & 0,984 & Fit \\
\hline TLI & $\geq 0,95$ & 0,987 & Fit \\
\hline CFI &
\end{tabular}

Source: Data processed by researchers (2019)

Based on the table above, it can be seen that seven (7) model suitability indicators have shown good values. The most important thing in assessing the Goodness of Fit Index from 
the overall model test results is its good chi-square value. If the other indices are met, it illustrates that the data is getting fit and the model is acceptable.

\section{Research Hypothesis Test}

In conducting the test of significance, the significance level $(\alpha)<5 \%$ was used to determine the significance of the direct effect between variables. The Regression Weights data were used on the AMOS output. Meanwhile, to assess the significance of the indirect effect between variables, a Sobel test will be used because the AMOS program does not produce an outcome of the indirect role significance. The following is the Regression Weights table from the results of the AMOS 22.00 calculation:

Table 2. Regression Weights Structural Equation Modeling

\begin{tabular}{|ccc|ccccc|}
\hline & & & Estimate & S.E. & C.R. & P & Label \\
\hline $\mathrm{Kp}$ & $<---$ & $\mathrm{Kl}$ &, 606 &, 061 & 9,932 & $* * *$ & par_13 \\
$\mathrm{Kp}$ & $<---$ & $\mathrm{Ha}$ &, 477 &, 084 & 5,653 & $* * *$ & par_14 \\
$\mathrm{Kn}$ & $<---$ & $\mathrm{Kl}$ &, 074 &, 138 &, 535 &, 593 & par_10 \\
$\mathrm{Kn}$ & $<---$ & $\mathrm{Ha}$ &, 329 &, 134 & 2,454 &, 014 & par_11 \\
$\mathrm{Kn}$ & $<---$ & $\mathrm{Kp}$ &, 754 &, 187 & 4,038 & $* * *$ & par_12 \\
\hline
\end{tabular}

Source: Data processed by researchers (2019)

The following are the results of the sobel test as a basis for the analysis of the hypothesis of this study:

Table 3. Sobel Test Results on Inter-Variable Mediation Effects Big Perception of Financing Margins -> Financing Application Decisions -> Customer Satisfaction.

\begin{tabular}{|c|c|c|c|}
\hline Input: & & Test statistic: & $p$-value: \\
\hline$t_{\mathrm{a}} 5.653$ & Sobel test: & 3.28581648 & 0.00101687 \\
\hline \multirow[t]{3}{*}{$t_{\mathrm{b}} 4.038$} & Aroian test: & 3.25229497 & 0.00114477 \\
\hline & Goodman test: & 3.32039635 & 0.0008989 \\
\hline & Reset all & \multicolumn{2}{|c|}{ Calculate } \\
\hline
\end{tabular}

Source: Data processed by researchers (2019) 
Table 4. Sobel Test Results on Inter-Variable Mediation Effects Service Quality -> Financing Application Decision -> Customer Satisfaction.

\begin{tabular}{|l|c|c|c||}
\hline \multicolumn{1}{|c|}{ Input: } & \multicolumn{1}{c|}{ Test statistic: } & \multicolumn{1}{c|}{$p$-value: } \\
$t_{\mathrm{a}} 9.932$ & & Sobel test: 3.7406615 & 0.00018354 \\
\hline$t_{\mathrm{b}} 4.038$ & & Aroian test: 3.72449608 & 0.00019571 \\
\hline & & Goodman test: 3.75703924 & 0.00017194 \\
\hline & Reset all & \multicolumn{2}{c|}{ Calculate } \\
\hline
\end{tabular}

Source: Data processed by researchers (2019)

Based on the results of the data analysis, it can be concluded that there is only an intervening effect in one of the pathways. The following is a summary of the research hypothesis test results which will be presented in table 5 below:

Table 5. Conclusion of Research Hypothesis Testing Results

\begin{tabular}{|c|l|c|}
\hline H1 & $\begin{array}{l}\text { There is a positive influence between the service quality } \\
\text { variables on the financing customer request decision } \\
\text { variables. }\end{array}$ & $\begin{array}{c}\text { Accepted } \\
(p<0,05)\end{array}$ \\
\hline H2 & $\begin{array}{l}\text { There is a positive influence between the variable perception } \\
\text { of the size of the financing margin on the variable of } \\
\text { financing customer request decisions. }\end{array}$ & $\begin{array}{l}\text { Accepted } \\
(p<0,05)\end{array}$ \\
\hline H3 & $\begin{array}{l}\text { There is a positive influence between service quality } \\
\text { variables on customer satisfaction variables. }\end{array}$ & $\begin{array}{l}\text { Rejected } \\
(p>0,05)\end{array}$ \\
\hline H4 & $\begin{array}{l}\text { There is a positive influence between the financing margin } \\
\text { variable on the customer satisfaction variable. }\end{array}$ & $\begin{array}{l}\text { Accepted } \\
(p<0,05)\end{array}$ \\
\hline H5 & $\begin{array}{l}\text { There is a positive influence between the variable financing } \\
\text { customer request decision on the customer satisfaction } \\
\text { variable. }\end{array}$ & $\begin{array}{l}\text { Accepted } \\
(p<0,05)\end{array}$ \\
\hline H6 & $\begin{array}{l}\text { There is a positive influence between the service quality } \\
\text { variable on the customer satisfaction variable mediated by } \\
\text { the financing request decision variable. }\end{array}$ & $\begin{array}{l}\text { Accepted } \\
(p<0,05)\end{array}$ \\
\hline
\end{tabular}

Source: Data processed by researchers (2019)

Service quality has a positive and significant effect on financing application decisions. This is indicated by the value of $\mathrm{CR}=9.932>1.96$ and a significance level of 0.001 (***), which is below 5 percent alpha. Thus the hypothesis $\mathrm{H} 1$ is proven in this analysis.

The perception of the size of the financing margin has a positive and significant effect on the decision to request financing. This is indicated by the value of $\mathrm{CR}=5.653>1.96$ and 
a significance level of $0.001(* * *)$, which is below 5 percent alpha. Thus the H2 hypothesis is proven in this analysis.

Service quality has no positive and insignificant effect on customer satisfaction. This is indicated by the value of $\mathrm{CR}=0.535<1.96$ and a significance level of 0.593 , which is above 5 percent alpha. Thus the hypothesis $\mathrm{H} 3$ is not proven in this analysis.

The perception of the size of the financing margin has a positive and significant effect on customer satisfaction. This is indicated by the value of $\mathrm{CR}=2.454>1.96$ and a significance level of 0.014 , which is below 5 percent alpha. Thus the hypothesis H4 is proven in this analysis.

The decision to request financing has a positive and significant effect on customer satisfaction variables. This is indicated by the value of $\mathrm{CR}=4.038>1.96$ and a significance level of $0.001(* * *)$, which is below 5 percent alpha. Thus the hypothesis H5 is proven in this analysis.

Service quality, financing request decisions, and customer satisfaction have a significant effect. This is indicated by a significance level of 0.00018 , which is below $5 \%$ alpha. Thus the hypothesis H6 is proven in this analysis.

There is a significant influence on the perception of the size of the financing margin, the decision on financing application, and customer satisfaction. This is indicated by a significance level of 0.0010 , which is below $5 \%$ alpha. Thus the hypothesis $\mathrm{H} 7$ is proven in this analysis.

\section{CONCLUSION}

Service quality has a positive and significant effect on financing application decisions. This is in line with Laksana (2011) research, Susanti (2016), which shows that service quality has a significant positive effect on customer financing request decisions.

The perception of the financing margin size has a positive and significant effect on the variable of financing customer application decisions. This is in line with Oktavianingrum's research (2016), which shows that financing margins positively impact financing customer application decisions.

Service quality has no positive and insignificant effect on customer satisfaction. It is necessary to do further studies, whether the variable service quality is not proven to the customer satisfaction variable because the research sample was conducted among internal 
customers (bank employees) or other things. By taking into account that the respondent has reduced sensitivity to the quality of service received when applying for financing, considering that the respondent is also a service provider at a specific time so that the expectation of the quality of service received by the respondent is not too high. The results of this study are different from those of Ika (2015), Widyasari (2017), Susanti (2016), which show that service quality has a positive effect on customer satisfaction.

The size of the financing margin has a positive and significant effect on customer satisfaction. The amount of the bank's financing margin is of concern to customers because this is related to the money to be paid. With this margin, customers can estimate the fair price of the bank's financing service products. Banking services that are of the same quality but set relatively cheaper financing margins will provide higher value to customers.

Customer satisfaction contributes to essential aspects of business activities, namely creating customer loyalty, increasing company reputation, reducing price elasticity, reducing future transaction costs, and increasing employee efficiency and productivity (Tjiptono, 2007). This is in line with the research of Susanti (2016) and Laksana (2011), which show that the financing margin has a positive effect on customer satisfaction.

The decision to request financing has a positive and significant effect on customer satisfaction variables. When consumers buy certain products and are satisfied with the performance of the product/service, consumers will often buy back the product whenever they need it. In this study, the customer makes a purchase decision in the form of a decision to request financing from the bank. In line with Roisah (2013) research, Ika (2015) stated that financing customer purchase decisions positively affects customer satisfaction.

There is a significant influence on the mediation of service quality variables, decision on financing requests, and customer satisfaction. Customers are satisfied when they get good service or what is expected. In line with Susanti's (2016), Ika (2015) research stated that service quality has a positive effect on financing customer purchasing decisions, impacting customer satisfaction.

There is a significant influence in the mediation of the variable perception of the size of the financing margin, the decision on financing application, and customer satisfaction. 
Banking services that are of the same quality but set relatively cheaper financing margins will provide higher value to customers. In line with Ika (2015), Susanti (2016) shows that financing margins have a positive effect on financing customer purchasing decisions which have an impact on customer satisfaction. So implication managerial from this research is banking services can increase financing margins that this is can relate with customer purchasing decision.

\section{References}

Abdillah, Willy \& Hartono, Jogiyanto (2015). Alternatif Structural Equation Modelling (SEM) dalam Penelitian Bisnis. Yogyakarta: Andi.

Ahidin, Udin \& Ribka, Stephany (2018), Membangun Kepuasan Nasabah melalui Kualitas Pelayanan Pada Nasabah Pinjaman PT BPR Prima Kredit Mandiri Cab. Ciputat Kota Tangerang Selatan. Jurnal Pemasaran Kompetitif Vol 1 No 2.

Arikunto, Suharsimi, (2010) Prosedur Penelitian Suatu Pendekatan Praktik, Jakarta: PT Rieneka Cipto.

Asiyah, Binti Nur (2014). Manajemen Pembiayaan Bank Syariah. Yogyakarta: Teras.

Bank Indonesia, (2018), Survei Pelanggan Indonesia Triwulan II-2018, sumber www.bi.go.id.

Bashir, Mohamed Sharif (2012), Analysis of Customer Satisfaction with the Islamic Banking Sector: Case of Brunei Darussalam, Asian Journal of Business and Management Sciences. ISSN: 2047-2528 Vol. 2 No. 10 [38-50].

Ferdinand, Augusty, (2002). Structural Equation Modelling dalam Penelitian Manajemen,

Edisi 2, Semarang: FE Undip.

Frangos, Christos C., et all (2012) Factors Affecting Customers' Decision for Taking out

Bank Loans: A Case of Greek Customers. IBIMA Publishing Journal of Marketing Research \& Case Studies Vol. 2012 (2012), Article ID 927167.

Frontier (2018). Top Brand Indeks 2018, sumber: www.topbrand-award.com.

Gardenia, Yulisa (2007), Pengaruh Kepuasan terhadap Loyalitas Nasabah Bank., Jurusan Manajemen, Fak Ekonomi, Universitas Gunadarma.

Hair, J. F Anderson R. E \& Tatham, R.L. (1998). Multivariate Data analysis, fifth Edition, New Jersey: Pretince Hall Inc. 
Hamid et all (2013), Customer's Preference on Islamic Banking And Services: The Influence Of Knowledge, Awareness, And Satisfaction. MARA, Malaysia, Malaysian Accounting Review Vol 12 no 1.

Ika, Vinansius dan Wihananto, Bambang (2015), Analisis Pengaruh Kebijakan Harga, Promosi dan Kualitas Pelayanan Terhadap Kepuasan Pelanggan di Hotel Sun City dan Luxury Club Jakarta, STIE Bisnis Indonesia.

Ikatan Bankir Indonesia (IBI). Mengelola Kredit secara Sehat, Modul Sertifikasi Bidang Kredit Tingkat I untuk Credit Officer, LSPP-IBI. (2016). Jakarta: PT Gramedia Pustaka Utama.

Irwinda N.T \& Andi Lolo (2011), Pengaruh Marketing Mix Terhadap Keputusan Konsumen Yang Menabung Pada PT. Bank Mandiri (Persero) Tbk. Cabang Makassar Kartini, Universitas Hasanudin.

Ivone, Olivia (2010), Pengaruh Kualitas Jasa terhadap Loyalitas nasabah Kredit di Mediasi dengan Variabel Kepuasan. (Studi Persepsi Nasabah pada Unit unit BRI Cabang Karanganyar, Universitas Sebelas Maret.

Juiati \& Emilia. (2017). Pengaruh Harga terhadap Keputusan Konsumen Membeli Rumah tipe 36 pada CV Perdana Laju Mandiri di Guntung Manggis Kota Banjarbaru. Jurnal Scientific Vol I Juli- Okt 2017.

Karim, Adiwarman (2007). Bank Islam, Analisis fikih dan Keuangan. Jakarta: PT Raja Grafindo Persada.

Kotler, Philip \& Keller, L. Kevin. (2009). Manajemen Pemasaran. Edisi 12, Jilid 1 dan 2. Jakarta: Erlangga.

Kotler, Philip \& Keller, L. Kevin. (2012). Marketing Management.15th Edition. New Jersey: Pearson Education, Inc.

Kotler, Philip dan Amstrong, Gary. (2009). Prinsip-Prinsip Pemasaran. Edisi 12, Jilid 1. Jakarta: Erlangga.

Laksana, Nyoni (2011), Pengaruh Persepsi Harga, Kualitas Pelayanan dan Lokasi terhadap Keputusan Nasabah dalam Pengabilan Kredit Berjangka Pada Bank Jateng Cabang Semarang.

Lovelock, Chirstopher \& Wirtz, Jochen, (2011), Services Marketing, People, Technology, Strategy, 7th Edition, New Jersey: Pretince Hall Inc. 
Lubis, A.R. S dan Chan, Syafrudin (2016), Penerapan Marketing Mix dan Keputusan Menabung Serta Dampaknya terhadap Loyalitas Nasabah Bank Pembiayaan Rakyat Syariah (BPRS) di Kota Banda Aceh dan Aceh Besar, Jurnal Manajemen Pascasarjana Universitas Syiah Kuala, SSN 2302-0199, pp 86-94, Volume 5 no 1.

Lupiyoadi, Rambat, (2006), Manajemen Pemasaran Jasa (Teori dan Praktek), Jakarta:

Salemba Empat.

Majalah Infobank Edisi no 484 Oktober 2018 Vol XL.

Majalah Property-in Edisi 9/IV/September 2018.

Nastiti N, Rizki dkk. (2013), Analisis Pengaruh Marketing Mix Terhadap Kepuasan Dan Loyalitas Pelanggan Dengan Metode Structural Equation Modelling (SEM). (Studi Kasus di UKM Teguh Raharjo Ponorogo), Universitas Brawijaya.

Oktavianingrum, Yesi dan Noor, Iswan (2016), Analisis Preferensi Nasabah terhadap

Pembiayaan Kredit Kepemilikan Rumah (KPR) antara Bank Umum Syariah Dan

Bank Umum Konvensional (Studi Kasus di Kota Malang), Fakultas Ekonomi dan Bisnis Universitas Brawijaya.

Rahmawaty, Anita (2015), Model Shariah Relationship Marketing dalam Meningkatkan

Kepuasan dan Loyalitas pada Lembaga Keuangan Mikro Syari'ah, Jurnal Ilmu Syari'ah dan Hukum. Vol. 49, No. 2

Ratmiko, Atik Septi Winarsih (2005). Manajemen Pelayanan, Pengembangan Model,

Konseptual, Penerapan Chapter \& Standar Pelayanan Minimal. Pustaka Pelajar: Yogyakarta.

Sa'adah, Nailus, (2010), Analisis Terhadap Alasan Masyarakat untuk menjadi Nasabah BNI Syariah ditinjau dari perspektif Marketing Mix, Konsentrasi Perbankan Syariah Prodi Muamalat (ekonomi Islam) Fakultas Syariah dan Hukum, Skripsi Universitas Syarif Hidayatullah Jakarta.

Santoso, Singgih, (2014). Statistik Parametrik: Konsep dan Aplikasi dengan SPSS, Jakarta: PT Elex Media Komputindo.

Sekaran, Uma and Bougie, Roger. (2010). Research Methods for Busines: A Skill Building Approach, London: John Willey and Sons, inc.

Sholihin, Mahfud \& Ratmono, Dwi (2013) Analisis SEM-PLS dengan WarpPLS 3.0 untuk Hubungan Nonlinier ddalam Penelitian Sosial dan Bisnis, Yogyakarta: Andi. 
Simamora, Elisabeth R. (2007), Analisis Faktor - Faktor yang Membangun Kepuasan Nasabah Untuk Meningkatkan Loyalitas Pelanggan (Studi Empiris Nasabah PT. Bank Tabungan Negara Cabang Semarang). Program Pasca Sarjana Universitas diponegoro Semarang.

Sugiyono (2010). Metode Penelitian Bisnis (Pendekatan Kuantitatif, Kualitatif dan RnD), Bandung: Rosda.

Sumarwan, Ujang (2011). Perilaku Konsumen: Teori dan Penerapannya dalam Pemasaran. Jakarta: PT Ghalia Indonesia.

Sunyoto, Danang. (2012). Dasar- dasar Manajemen Pemasaran: Konsep, Strategi dan Kasus. Yogyakarta: CAPS.

Susanti, Deery Anzar (2016), Analisis Pegaruh Harga, Promosi, Pelayanan dan Kualitas Produk Online terhadap Kepuasan konsumen Online secara Syariah. STAI Jam'iyah Mahmudiyah Tanjung Pura Langkat, Jurnal Analytica Islamica, Vol 5, No 2.

Tjiptono, Fandy, (2007). Pemasaran Jasa. Edisi 1. Malang: Bayumedia Publishing.

Widyasari dkk (2017), Pengaruh Kualitas Produk, Persepsi Harga dan Citra Merk terhadap Kepuasan serta Dampaknya pada Loyalitas Pelanggan (Studi Empiris pada Koran Harian Suara Merdeka di Kota Semarang), Universitas Stikubank Semarang. Jurnal Manajemen Bisnis Indonesia Vol 5 no 1.

Yulisafitri, Roisah, R. dan Iskandar, I. (2013), Pengaruh Strategi Pemasaran terhadap Kepuasan Nasabah pada PT Bank Tabungan Negara KCP Kopo. Fak Ekonomi, Universitas BSI.

Zeithaml, Valerie A \& Bitner, Mary jo. (2003). Service Marketing. New York: McGraw Hill Inc, Int'l Edition. 